\title{
IMPLEMENTASI PRINSIP KERJASAMA MAHASISWA MULTIKULTURAL DI KOTA MALANG
}

\section{Munawwir Hadiwijaya*, Maya Rizki Amalyasari}

Pendidikan Bahasa Inggris, FPISH, IKIP Budi Utomo, Jl. Citandui No 46 Malang, Indonesia

* Corresponding author: mr.awinwijaya@gmail.com

\section{INFORMASI ARTIKEL}

Sejarah Artikel

Diterima: 21/8/2019

Direvisi: $23 / 11 / 2019$

Diterima: $25 / 12 / 2019$

Tersedia Daring: 30/12/2019

\section{Kata Kunci}

Prinsip Kerjasama

Mahasiswa Multikultural

Komunikasi
Penelitian ini bertujuan untuk mengetahui implementasi Prinsip Kerja Sama Grice pada mahasiswa multikultural yang belajar di Malang, berdasarkan pelanggaran, pembatasan, dan implikatur yang ditimbulkan. Desain penelitian ini adalah deskriptif kualitatif. Sumber data diperoleh dari dialog yang muncul dalam interaksi sehari-hari antara mahasiswa multikultural di dalam dan di luar kelas di IKIP Budi Utomo Malang, yang didominasi oleh enam suku, yaitu: Jawa, Madura, Dayak/Pontianak, Sumba Flores, dan Makasar. Dari hasil penelitian ini diketahui bahwa: (a) pelanggaran Maksim Kuantitas memiliki implikatur: penekanan, penolakan, dan dalam situasi di mana pembicara dan mitra bicara memiliki referensi yang sama dan anggapan yang sesuai; (b) Pelanggaran Kualitas Maxim memiliki implikatur: Menerka-nerka karena tidak yakin tentang informasi yang disampaikan, basa-basi untuk kesopanan, dan berkelit; (c) Pelanggaran Maksim Relevansi memiliki implikatur: penegasan pernyataan atau pendapat dari mitra tutur; (d) Pola Pelanggaran Maksim Cara bermotif: menjaga pembicaraan berlangsung lebih lama; (e) Pembatasan Maksim Kuantitas berpola: memberikan kesan kepada mitra bicara bahwa informasi yang diberikan mungkin tidak cukup lengkap; (f) Pembatasan Maksim Kualitas berpola: penutur tidak bertanggung jawab atas kebenaran kata-katanya; (g) Pembatasan Maksim Relevansi berpola: mengubah topik pembicaraan tanpa menyinggung mitra tutur; (h) Dalam penelitian ini tidak ada kasus Pembatasan Maksim Cara karena data yang diperoleh terbatas.

\section{Keywords}

Cooperative Principles

Multicultural Students

Communication
This study aims to describe the implementation of Grice's Cooperative Principles of multicultural students in Malang, based on violations, hedges, and implicatures. The design of this study is descriptive qualitative. The data sources obtained from dialogues that arise in daily interactions among multicultural students inside and outside the classroom at IKIP Budi Utomo Malang, which is dominated by six tribes, they are: Javanese, Madurese, Dayaks/Pontianak, Sumba Flores, and Makassar. From the results of this study it is known that: (a) violations of Quantity Maxim patterned: emphasis, denial, and in situations where both the speaker and the speech partner have the same reference and appropriate presupposition; (b) Violation of Quality Maxim patterned: Guess for not being sure of the information conveyed, chit chat for politeness, and circumventing; (c) Violation of Relevance Maxim patterned: affirmation of the statement or opinion of the speech partner; (d) Violation of Manner Maxim patterned: keep the conversation going longer; (e) Hedging of Quantity Maxim Patterned: gives the impression to the speech partner that the information provided may not be sufficiently complete; (f) Hedging of Quality Maxim: the speaker is not responsible for the truth of his words; (g) Hedging of Relevance Maxim: change the topic of conversation without offending the speech partner; (h) In this study there are no case of Manner Maxim hedged due to the limited data obtained. 

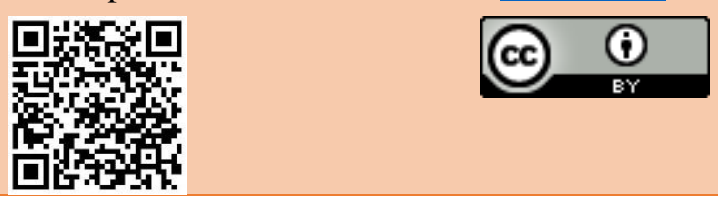

\section{PENDAHULUAN}

Banyaknya kampus-kampus di Kota Malang telah menjadikan Kota ini sebagai tujuan mahasiswa dari berbagai daerah di Indonesia untuk menuntut ilmu. Oleh karena itu, situasi ini membentuk masyarakat yang bersifat multikultural. Masyarakat multikultural adalah suatu masyarakat yang anggotanya datang dari berbagai suku, ras, maupun agama yang berbedabeda, dimana terdapat tata nilai yang dipegang bersama, tetapi masih terdapat segmen-segmen yang tidak dapat disatukan karena tiap-tiap anggotanya memiliki ikatan primordial kedaerahan masing-masing. Masyarakat dimana elemen-elemen pembentuknya bersifat majemuk, baik dari segi suku, ras, maupun agama, yang membentuk struktur organisasi dan sistem nilai yang telah disepakati bersama, dimana tiap individu sederajat, memiliki hak dan kewajiban yang sama.

Terdapat beberapa ciri dalam masyarakat multikultural yang meliputi; (1) anggota dari masyarakat tersebut memiliki latar belakang yang beragam, baik dari segi suku, ras, maupun agama, yang tentu saja memiliki prinsip primordialisme yang berbeda-beda pula. Tak jarang dari prinsip primordialisme yang terlalu dipegang kuat oleh anggotanya mengakibatkan sering terjadinya konflik antar mereka; (2) terdapat sistem nilai yang menjadi landasan hidup bermasyarakat dan struktur organisasi yang berfungsi sebagai regulator dan sarana interaksi yang telah disepakati oleh anggotanya; (3) consensus atau musyawarah merupakan sarana utama dalam pengambilan keputusan (Lestari, 2015).

Tipe masyarakat ini tentu saja harus memiliki suatu hal yang dapat digunakan bersama terutama dalam bahasa untuk berinteraksi. Bahasa Indonesia yang telah menjadi bahasa nasional bangsa Indonesia berperan sangat penting dalam hal komunikasi antar masyarakat yang berbeda suku dan budaya. Artinya bahasa Indonesia telah berkembang luas dan menjadi bahasa pengantar dalam berkomunikasi antar dan inter masyarakat.

Meskipun tidak ada kesulitan yang berarti dalam hal berkomunikasi antara mahasiswa yang berbeda suku, adanya perbedaan adat dan budaya tentunya menimbulkan situasi yang menarik untuk diamati. Dari segi kesantunan misalnya, meskipun mereka masih memiliki ikatan primordial kedaerahan yang masih sangat kuat, pola kesantunan secara umum antara mahasiswa multikultural memiliki banyak kesamaan. Pola-pola umum yang lazimnya digunakan para mahasiswa dalam interaksinya antar mereka, antara lain: penggunaan ungkapan salam ketika mengawali percakapan, penggunaan ungkapan maaf juga ketika mengawali percakapan, penyebutan honorifik tertentu, seperti Bapak, Ibu, Prof. dll, dan yang terakhir penggunaan ungkapan terima kasih ketika mengakhiri percakapan (Hadiwijaya \& Yahmun, 2017).

Akan tetapi, kesantunan saja tidaklah cukup agar komunikasi dapat berjalan dengan baik. Kontribusi dalam percapakan adalah aspek lain yang tidak kalah penting dalam komunikasi. Dalam berkomunikasi, baik penutur dan mitra tutur diharapkan berkontribusi sesuai dengan topik yang dibahas. Beragam kontribusi timbul dalam komunikasi pergaulan mahasiswa multikultural di Kota Malang yang tidak jarang menimbulkan kesalahpahaman hingga konflik antar mereka yang berbeda. Kontribusi yang berlebihan ataupun yang tidak mengandung kebenaran atau terdapat keraguan dapat menyesatkan mitra tutur. Sedangkan kontribusi yang kurang relevan dan bertelele-tele dapat menimbulkan kesalahpahaman.

Oleh karenanya, prinsip kerjasama yang merupakan salah satu aspek komunikasi yang 
juga sangat penting haruslah diketahui oleh penutur. Prinsip Kerjasama (PK) yang diperkenalkan H.P. Grice (1967) menjadi relevan dan penting untuk dikaji. Pada prinsipnya, PK adalah suatu kaidah dalam berkomunikasi agar dapat berjalan efektif dan efisien, yang mampu meminimalisir kesalahpahaman yang dapat mengakibatkan terjadinya konflik. Grice membagi PK menjadi empat bidal sebagai berikut: maksim kuantitas (maxim of quantity), maksim kualitas (maxim of quality), maksim relevansi (maxim of relevance), dan maksim cara (maxim of manner). Tiap-tiap bidal memiliki subbidal yang merupakan aturan-aturan yang mendetail tentang bagaimana berkontribusi dalam suatu komunikasi. Pelanggaran PK biasanya mengakibatkan gagalnya komunikasi, terkecuali jika ada maksud tersirat (implikatur) yang terdapat dalam ujaran penutur yang mampu diterima dengan baik oleh mitra tutur.

Pertama Maksim Kuantitas, dalam menjelaskan maksim kuantitas, Kroeger (2018) menyatakan bahwa, dalam sebuah percakapan seyogyanya penutur memberikan informasi yang cukup, tidak terlalu sedikit yang bisa menyebabkan ketidakpahaman mitra tutur ataupun terlalu banyak yang dapat menyebabkan mitra tutur teralihkan dari fokus pembicaraan.

Kedua Maksim Kualitas, Liu (2017) menjelaskan bahwa inti dari maksim ini adalah menuntut penutur untuk memberikan informasi sebenar-benarnya dalam sebuah percakapan, meliputi dua aspek yang disebut oleh Grice (1991) sebagai sub maksim, yaitu: (1) jangan memberikan informasi yang belum pasti kebenarannya; (2) jangan memberikan informasi yang penutur sendiri tidak punya cukup bukti akan kebenarannya.

Ketiga Maksim Relevansi, inti dari maksim ini adalah kontribusi yang relevan terhadap topik yang sedang dibahas. Isi dari maksim ini adalah "be relevant" yang maksudnya dijabarkan oleh Senft (2014) sebagai bidal yang mengharuskan penutur agar memberikan kontribusi yang relevan sesuai dengan tujuan yang diasumsikan saat ini dari orang-orang yang terlibat dalam percakapan tersebut.

Maksim ini juga oleh sebagian skolar disebut maksim relasi, Birner (2012) berpendapat istilah relasi lebih tepat untuk menyebut maksim ini, karena ujaran yang dituturkan haruslah memiliki keterkaitan dengan ujaran sebelum maupun sesudahnya. Lebih luas, ujaran harus terkait dan terikat dengan konteks yang melekat pada percakapan tersebut, baik secara tekstual maupun situasional.

Terakhir Maksim Cara, "Be perspicuous!" (mudahlah dipahami), adalah super maksim dari maksim cara. Terdapat empat aspek yang menjadi fokus dari maksim ini yang dijabarkan dalam empat sub maksim, yaitu: Hindari ketidakjelasan ekspresi, hindari ambiguitas, singkat (hindari hal yang bertele-tele), teraturlah" (Birner, 2012; Grice, 1991; Kroeger, 2018; Senft, 2014).

Terdapat beberapa penelitian tentang prinsip kerjasama dan interaksi masyarakat multikultural, di antaranya, penelitian tentang aplikasi Prinsip Kerjasama oleh siswa di sekolah yang dilakukan oleh Achsani (2019). Penelitian ini berkesimpulan bahwa dalam berinteraksi para siswa lebih banyak menggunakan maksim relevansi. Sedangkan dalam hal pelanggaran maksim didominasi oleh pelanggaran maksim kuantitas dengan pola mempertegas atau memperjelas informasi yang disampaikan. Penelitian yang hampir serupa juga pernah dilakukan oleh Zhou (2009), dimana penelitian ini berkesimpulan bahwa pengaplikasian prinsip kerjasama dalam pembelajaran kelas speaking mampu meningkatkan kompetensi komunikatif siswa. Sedangkan penelitian tentang interaksi bahasa masyarakat multikultural yang berfokus pada respon pujian oleh mahasiswa multikultural (Rachman \& Kinanti, 2018). Dari penelitian ini diketahui bahwa terdapat beberapa strategi mahasiswa dalam merespon pujian, baik menolak ataupun menerima bahkan ada juga yang menafsirkan pujian dengan hal lain dan sebagainya. Penelitian ini hanya berfokus pada pujian saja, aspek komunikasi dan interaksi yang lain belum tersentuh oleh penelitian ini. 
Berdasarkan uraian di atas, tujuan utama dari penelitian ini adalah untuk mengungkap bagaimana implementasi prinsip kerjasama dalam interaksi antara mahasiswa multikultural ditinjau dari kerangka teori prinsip kerjasama Grice.

\section{METODE}

Merujuk pada tujuan dari penelitian pada bab pendahuluan, penelitian ini dicategorikan sebagai penelitian kualitatif deskriptif. Sumber data dari penelitian ini diperoleh dari dialog-dialog yang muncul dalam interaksi sehari-hari baik antar mahasiswa multikultural di dalam dan luar kelas di IKIP Budi Utomo Malang, yang kemudian dijadikan bentuk petikan-petikan yang dihasilkan dari transkrip dialog-dialog tersebut. Instrumen utama dari penelitian ini adalah peneliti sendiri. Peneliti dalam hal ini berperan sebagai pengumpul dan penganalisa data. Dalam melakukan penelitiannya peneliti akan menggunakan instrumeninstrumen pendukung untuk mengumpulkan dan menganalisa data, seperti: catatan lapangan dan perekam. Data dari penelitian ini diperoleh melalui proses perekaman dialog-dialog yang muncul dalam interaksi sehari-hari baik antar mahasiswa multikultural dalam dan luar kelas di IKIP Budi Utomo Malang dan catatan lapangan selama interaksi tersebut berlangsung.

Terdapat tiga fase Analisa data dalam penelitian ini, yaitu: Reduksi Data, Penyajian Data, dan Penarikan Kesimpulan. Reduksi data dilakukan untuk memisahkan semua data sesuai dengan pelanggaran dan pembatasan prinsip kerjasama Grice. Dalam penelitian ini dilakukan dengan menggunakan beberapa indikator, yang dijabarkan dalam Tabel 1 dan 2 . Dari 476 ujaran yang direkam, terdapat 45 ujaran yang sesuai dengan indikator yang telah disusun.

Tabel 1

Indikator Ketaatan dan Pelanggaran Maksim Prinsip Kerjasama

\begin{tabular}{|c|c|c|c|}
\hline \multirow[t]{2}{*}{ No. } & \multirow[t]{2}{*}{ Maksim } & \multicolumn{2}{|r|}{ Indikator } \\
\hline & & Ketaatan & Pelanggaran \\
\hline \multirow[t]{2}{*}{1.} & Kuantitas & 1. Tidak berlebihan & 1. Berlebihan \\
\hline & & 2. Informatif & 2. Kurang informatif \\
\hline 2. & Kualitas & $\begin{array}{l}\text { 1. Sesuai kenyataan } \\
\text { 2. Didukung dengan } \\
\text { cukup bukti }\end{array}$ & $\begin{array}{l}\text { 1. Tidak sesuai kenyataan } \\
\text { 2. Tidak didukung dengan cukup } \\
\text { bukti }\end{array}$ \\
\hline 3. & Relevansi & Sesuai topik & Tidak sesuai topik \\
\hline \multirow[t]{3}{*}{4.} & Cara & 1. Mudah dipahami & 1. Tidak jelas \\
\hline & & 2. Singkat & 2. Bertele-tele \\
\hline & & 3. Runtut & 3. Kacau \\
\hline
\end{tabular}

Tabel 2

Indikator Pembatasan Maksim Prinsip Kerjasama

\begin{tabular}{lll}
\hline No. & \multicolumn{1}{c}{ Maksim } & \multicolumn{1}{c}{ Indikator } \\
\hline 1. & Kuantitas & Terbatasi \\
\hline 2. & Kualitas & Kurangnya komitmen atas kebenaran informasi \\
\hline 3. & Relevansi & Tidak relevan \\
\hline 4. & Cara & Tidak jelas \\
\hline
\end{tabular}

Dalam penelitian ini data yang diperoleh disajikan dalam bentuk tabel yang dapat dilihat dalam Tabel 3 pada bab selanjutnya. Sebelumnya, data yang berupa transkripsi percakapan dikelompokkan berdasarkan suku dalam bentuk tabel untuk selanjutnya direduksi berdasarkan indikator yang ada. Setelah data tereduksi, data yang sesuai dianalisa lebih detail dengan mencari kata, frasa, atau kalimat yang memicu adanya pelanggaran dan pembatasan. Langkah selanjutnya dari ujaran-ujaran yang terdapat pelanggaran dan pembatasan di 
dalamnya diinterpretasi untuk mendeteksi adanya implikatur yang mungkin dimunculkan. Dari data yang sudah dianalisa ditarik kesimpulan sementara tentang pola pelanggaran dan pembatasan prinsip kerjasama Grice tiap-tiap suku.

\section{HASIL DAN PEMBAHASAN \\ HASIL}

Di bagian ini akan dibahas temuan-temuan yang ada dalam penelitian ini, yang secara general dapat dilihat dalam Tabel 3 di bawah ini:

Table 3 Penyajian Data Pelanggaran dan Pembatasan Maksim Prinsip Kerjasama

\begin{tabular}{|c|c|c|c|c|c|c|}
\hline \multirow{2}{*}{ Suku } & \multicolumn{2}{|c|}{ Jumlah Pernyataan } & \multicolumn{2}{|c|}{$\begin{array}{c}\text { Jumlah Kasus } \\
\text { Pelanggaran }\end{array}$} & \multicolumn{2}{|c|}{$\begin{array}{c}\text { Jumlah Kasus } \\
\text { Pembatasan }\end{array}$} \\
\hline & Angka & $\%$ & Angka & $\%$ & Angka & $\%$ \\
\hline Jawa & 154 & $2,35^{3}$ & 20 & $4,44^{4}$ & 3 & 25 \\
\hline Madura & 47 & $87^{9,}$ & 6 & $3,33^{1}$ & 1 & $3^{8,3}$ \\
\hline Sumba & 116 & $4,36^{2}$ & 13 & $8,88^{2}$ & 1 & $3^{8,3}$ \\
\hline $\begin{array}{l}\text { Pontiana } \\
\mathrm{k}\end{array}$ & 101 & $1,21^{2}$ & 4 & $88^{8,}$ & 2 & $66^{16,}$ \\
\hline Flores & 27 & $67^{5,}$ & 1 & $2^{2,}$ & 2 & $6^{16,}$ \\
\hline Makasar & 31 & $53^{6,}$ & 1 & $22^{2,}$ & 3 & 25 \\
\hline Total & 476 & $00 \%$ & 45 & $00 \%{ }^{1}$ & 12 & $0 \%^{10}$ \\
\hline
\end{tabular}

Dalam tabel di atas diketahui bahwa terdapat 476 ujaran yang diperoleh dalam proses pengumpulan data yang dilakukan melalui perekaman dialog mahasiswa dari berbagai suku antara lain: Jawa, Madura, Sumba, Pontianak, Flores, dan Makasar. Dari 476 ujaran tersebut setelah direduksi berdasarkan indikator pelanggaran dan pembatasan prinsip kerjasama Grice (Tabel 1 dan 2), terdapat 45 kasus pelanggaran dan pembatasan. Kasus-kasus tersebut didominasi oleh para mahasiswa Jawa dengan 23 kasus dari total 154 ujaran. Selanjutnya mahasiswa Madura 7 kasus dari 47 ujaran, mahasiswa Sumba dengan 14 kasus dari 116 ujaran, mahasiswa Pontianak 6 dari 101 ujaran, Flores 3 dari 27, dan terakhir Makassar 4 dari 31, yang secara detail akan dibahas dalam sesi selanjutnya.

\section{Pelanggaran Maksim Kuantitas}

Dari total 476 ujaran, terdapat delapan kasus pelanggaran maksim kuantitas yang dilakukan oleh para mahasiswa multikultural, Jawa, Pontianak, Madura, dan Sumba. Dari dua indikator yang ditetapkan untuk mendeteksi pelanggaran maksim ini, 12 dari 18 kasus yang ada merupakan pelanggaran dengan memberikan kontribusi yang berlebihan. Kasus kontribusi yang berlebihan dari data yang diperoleh dapat terkategori ke dalam tiga jenis ujaran:

a) Memberikan detail informasi yang tidak perlu, yang memunculkan implikatur penekanan. Berikut adalah contoh dari pelanggaran maksim kuantitas yang memiliki implikatur penekanan dengan menggunakan repetisi: 


\section{J1/D1/1}

F : Ok, mba Ay asli Malang kah?

A : Asli, asli Malang, lahir di Malang sampai sekarang di Malang.”

Pernyataan A, "lahir di Malang sampai sekarang di Malang." Tidaklah diperlukan dalam penggalan percakapan di atas. Dengan hanya menjawab dengan "Asli Malang" F seharusnya sudah paham apa yang dimaksud oleh A. implikatur yang mungkin dimunculkan dari pelanggaran tersebut adalah, A ingin menekankan bahwa A benar-benar berasal dari Kota Malang. A mengulang kata Malang sebanyak tiga kali, untuk memberi penekanan pada pernyataannya yang pertama, "Asli Malang".

b) Memberikan detail informasi yang tidak perlu dengan implikatur negasi (penyangkalan/ penolakan), seperti contoh di bawah ini:

\section{J4/D4/8}

D : Mas ndak makan?

M : Tadi pagi, kalo kebanyakan makan diluar itu tambah boros, saya itu sudah planning Jangan terlalu boros, ternyata masih boros aja. Dulu itu saya semester satu itu Jadi, cukup lima puluh ribu untuk tiga hari jajan. Sekarang satu hari itu habis itu.

Pernyataan $\mathrm{M}$ dalam menjawab pertanyaan $\mathrm{D}$, berdasarkan indikator dari penelitian ini, melanggar tiga maksim sekaligus, yaitu: kuantitas, relevansi, dan cara. $\mathrm{M}$ ingin menolak ajakan D untuk makan dengan memberikan penjelasan Panjang lebar, yang intinya $\mathrm{M}$ ingin berhemat. Tentu saja dengan menjawab "saya sudah makan tadi pagi" sudah cukup dan tuntas menjawab ajakan D. Akan tetapi, M lebih memilih untuk menyampaikan penolakannya dengan cara yang tidak langsung untuk menunjukkan sedikit kesopanannya kepada D.

c) Situasi dimana baik penutur maupun mitra tutur memiliki referensi yang sama dan presupposisi yang tepat pula

Sedangkan pelanggaran maksim kuantitas dengan indikator ke dua, kurang informatif, terdapat enam kasus. Ke duanya terjadi jika dalam percakapan tersebut baik penutur maupun mitra tutur memiliki referensi yang sama dan presupposisi yang tepat pula. Penggalan percakapan berikut menunjukkan pola tersebut:

\section{J2/D2/11}

M : Mau nyari buku apa aku ini nanti ya, sek tak chat Mila ya?

F : Coba cek di Wilis"

\section{Pelanggaran Maksim Kualitas}

Pola umum pelanggaran maksim ini dari semua mahasiswa multikultural adalah tidak adanya bukti yang mendukung pernyataan yang dilontarkan, dengan hanya menerka tentang kebenaran sesuatu. Hal ini biasanya dilakukan agar percakapan dapat berlangsung lebih lama atau tidak mau disangka kurang update. Jarang sekali para mahasiswa memberikan informasi palsu yang merupakan indikator yang ke dua. Secara keseluruhan terdapat 11 kasus pelanggaran dari 476 ujaran yang terekam, yang didominasi oleh mahasiswa Jawa, Madura, dan Sumba.

Terdapat empat pola umum yang teridentifikasi pelanggaran maksim kualitas yang dilakukan oleh para mahasiswa multikultural yang dibahas di bawah ini: 
a) Menerka-nerka karena tidak yakin atas informasi yang disampaikan

Seperti dinyatakan dalam sesi sebelumnya bahwa pelanggaran maksim ini didominasi oleh pelanggaran dengan indikator pertama yaitu kurang didukung dengan bukti yang cukup.

\section{$\mathbf{J 1} / \mathrm{D} 1 / 3$}

F : Makanan yang paling khas di Malang itu makanan apa?

A : Paling khas di mana-mana ada itu. Terus apa ya, rawon. Disana ada rawon ga?

Pernyataan yang dicetak miring tentu saja melanggar maksim kualitas. A yang berasal dari kota Malang tidak terlalu yakin atas jawaban pertanyaan $\mathrm{F}$ oleh karenanya A hanya menerka-nerka saja dan untuk menutupi hal tersebut A mencoba untuk mengalihkan pembicaraan dengan mengajukan pertanyaan kepada $\mathrm{F}$.

\section{b) Basa-basi untuk kesantunan}

Sedangkan pola dengan indikator kedua tidak sesuai kenyataan, biasanya digunakan untuk basa-basi demi kesantunan, seperti kasus berikut:

\section{J4/D4/7 \\ W : Dek, Sul, semuanya makan yok. \\ M : Kau tawar begitu andai mereka semua makan gimana? \\ W : Tinggal suruh pesan.}

W hanya berbasa-basi untuk kesopanan dengan menawarkan mitra tuturnya untuk makan. Meskipun demikian, ujaran tersebut terkategori melanggar maksim kualitas, karena memang penutur tidak bersungguh-sungguh dengan ucapannya.

c) Berkelit

Dari beberapa ujaran yang terekam, terdapat tiga kasus pelanggaran yang dilakukan oleh mahasiswa Sumba dengan indikator yang kedua. Berikut adalah salah satu kasus yang ditemukan:

\section{S1/D3/6}

$\mathrm{U} \quad$ : Tunggu-tunggu andaikan ditanya, kamu mau jawab apa?

A : Teman saya itu

Ar : Siapa, terus apa hubungannya sama saya, apa hubungannya, kok disangkut pautkan sama saya? Ko jawab apa?

A : (tertawa)

A yang merasa terpojok atas pertanyaan $\mathrm{U}$ berusaha berkelit dengan sedikit berbohong dengan menjawab "teman saya itu", jawaban sepontan untuk membela diri. A tahu persis bahwa apa yang telah ia lakukan adalah suatu yang salah.

\section{Pelanggaran Maksim Relevansi}

Dalam penelitian ini terdapat sepuluh kasus pelanggaran maksim ini, yang didomonasi oleh ujaran mahasiswa Jawa, Sumba, dan Madura. Pelanggaran maksim relevansi yang dilakukan oleh mahasiswa multikultur umumnya berpola afirmasi terhadap pernyataan atau pendapat mitra tutur, seperti: 


\section{P2/D4/3}

M : Kelas A saja itu, mereka itu tujuannya mau jalan-jalan kesana itu sebagian, bukan mau...

D : Pastikan emm, siapa sih yang ndak tau anak kuliahan.

M yang menjelaskan tentang suatu program kampus yang berlangsung di Surabaya. $M$ berpendapat bahwa teman-temannya yang ikut program tersebut memiliki agenda berbeda, yaitu jalan-jalan bukan memprioritaskan tugas magangnya. Pendapat ini disetujui oleh D, akan tetapi tidak dengan secara langsung melainkan dengan pernyataan yang tidak relevan. Dari sepuluh ujaran yang ditemukan melanggar maksim relevansi, hampir semua memiliki pola yang sama.

\section{Pelanggaran Maksim Cara}

Dalam penelitian ini ditemukan tujuh kasus pelanggaran maksim cara yang didominasi oleh ujaran yang bertele-tele. Implikatur yang ditimbulkan dari pelanggaran-pelanggaran yang terindikasi bertele-tele bermacam-macam, akan tetapi semua memiliki kesamaan dalam tujuan yaitu menjaga agar percakapan dapat berjalan lebih lama, seperti contoh dibawah ini:

\section{P3/D5/7}

A : Kalian suka nggak sih tinggal di Malang

M : Aku sih yaa suka nggak suka ya jalani aja kan udah kewajibannya, kalo misalkan kita nggak suka yah tetep jalani gitu aja tapi kalo aku pribadi sih suka banget sih disini banyak temen.

Respon M sangatlah bertele-tele, dengan hanya menjawab dengan kalimat terakhir sudahlah cukup.

\section{Pembatasan Maksim}

Dalam penelitian ini terdapat 12 kasus pembatasan dengan rincian sebagai berikut: tiga kasus pembatasan maksim kuantitas, yang masing-masing dilakukan oleh mahasiswa Jawa, Pontianak, dan Sumba; kasus pembatasan maksim kualitas yang teridentifikasi berjumlah enam kasus, yang dilakukan oleh mahasiswa Jawa, Flores, Madura, dan Pontianak; dan terakhir, pembatasan maksim relevansi terdapat tiga kasus yang ke semuanya dilakukan oleh mahasiswa Makassar. Pembatasan-pembatasan tersebut diulas di bawah ini:

Pertama, Pembatasan Maksim Kuantitas, Fraser (2010) menyatakan bahwa pembatasan maksim kuantitas bertumpu pada ide bahwa informasi yang ingin disampaikan terbatas. Pembatasan maksim ini memberikan kesan bagi mitra tutur bahwa informasi yang diberikan mungkin tidak cukup lengkap. Perhatikan penggalan percakapan di bawah ini:

\section{P3/D5/8}

A : Kalian udah jalan-jalan kemana mana gitu ya?

M : Waduh udah banyak sekali $\mathrm{Na}$

A : Iyakah, duhh apalah aku yang cuma tinggal di kos aja

Dari penggaalan percakapan di atas, tampak bahwa $\mathrm{M}$ melakukan pembatasan informasi yang ingin disampaikan. Dengan mengatakan "udah banyak sekali", M memberikan jawaban berupa estimasi, yang artinya $M$ tidak ingin memberikan detail informasi yang mungkin diinginkan oleh $\mathrm{A}$. 
Kedua, Pembatasan Maksim Kualitas, ide dari pembatasan maksim kualitas adalah penutur tidak bertanggung jawab atas kebenaran ucapannya. Misalnya:

\section{F1/D1/4}

F $\quad$ : Iya, mereka bilang enak tapi saya belum pernah coba.

Dari penggalan ujaran di atas, dengan mengatakan "mereka bilang" $\mathrm{F}$ ingin menyampaikan bahwa dia kurang berkomitmen atas kebenaran informasi yang akan dia sampaikan. Artinya, informasi yang dia sampaikan bukan murni dari dia melainkan orang lain.

Ketiga, Pembatasan Maksim Relevansi, yang bertitik berat pada merubah topik pembicaraan tanpa menyinggung mitra tutur, biasanya hal ini dilakukan secara tidak langsung. Berikut adalah contoh pembatasan maksim relevansi yang dilakukan mahasiswa Makassar:

\section{Mk1/D5/6}

$\mathrm{R} \quad$ : iya, belum lagi ke Pontianaknya kan naik travel lagi baru sampe rumah

A : : ya ampun, hmm aku bingung nih mau ngomong apa

A : kalian suka nggak sih tinggal di Malang

Dari penggalan percakapan di atas, A mencoba untuk membuka topik pembicaraan baru dengan mengatakan ujaran yang dicetak miring.

Keempat, Pembatasan Maksim Cara. Dalam penelitian ini tidak diketemukan kasus pembatasan maksim cara, hal ini dimungkinkan karena keterbatasan data yang diperoleh.

\section{PEMBAHASAN}

\section{Pelanggaran Maksim Kuantitas}

Inti dari Maksim Kuantitas adalah memberikan kontribusi dalam percakapan sesuai dengan yang diharapkan. Maksim ini memiliki dua submaksim, yaitu jangan memberikan informasi yang berlebihan dan jangan memberikan informasi yang kurang (Birner, 2012). Hasil penelitian ini menunjukkan bahwa terdapat tiga pola besar pelanggaran masksim ini, yaitu: penekanan, negasi, dan situasi dimana baik penutur maupun mitra tutur memiliki referensi yang sama dan presupposisi yang tepat pula.

Dalam bahasan kohesi leksikal, penekanan dapat dilakukan dengan menggunakan reiterasi, yaitu pengulangan kata-kata pada kalimat berikutnya untuk menunjukkan bahwa kata tersebut merupakan fokus pembicaraan. Terdapat beberapa bentuk reiterasi, seperti, repetisi, sinonim, hiponimi, metonimi, dan antonimi (Parwati, 2013). Pemberian detail informasi yang berlebihan dapat menyebabkan terlanggarnya maksim kuantitas. Sebagian penutur sering sengaja mendetailkan keterangan yang diberikan dengan tujuan untuk menekankan inti dari pernyataannya.

Kecenderungan yang kedua yaitu penolakan atau negasi. Negasi adalah penyangkalan atau penolakan terhadap sesuatu hal. Mappau (2017) menyatakan bahwa fungsi utama negasi adalah untuk menyangkal pernyataan mitra tutur yang dianggap kurang tepat atau keliru oleh penutur atau menolak sesuatu. Bentuk dari penolakan memiliki bentuk yang bervariasi, baik secara langsung maupun tidak. Dari penelitian ini dapat diketahui bahwa bentuk-bentuk penolakan yang digunakan sangat erat hubungannya dengan nilai primordialisme yang dipegang oleh masing-masing penutur. Suku Jawa, misalnya, kecenderungan penolakan berbentuk pernyataan tidak langsung. Memberikan detail informasi yang tidak perlu dengan 
implikatur negasi (penyangkalan/penolakan) adalah umum dilakukan oleh mahasiswa Jawa, mengingat kentalnya adat Jawa yang mempengaruhi perilaku masyarakatnya, banyak pertimbangan yang diambil ketika harus bertutur, yang kesemuanya bermuara kepada perasaan mitra tutur. Jika orang Jawa akan sengaja menggunakan bahasa yang bertele-tele untuk mengungkapkan penolakannya. Hal ini berbeda dengan suku lain yang memberikan penolakan dengan cara langsung, seperti Pontianak, Flores, dan Sumba. Hal ini adalah lazim ditemukan dalam interaksi mahasiswa multikultural.

Yang ketiga yaitu adanya persamaan referensi. Referensi merujuk pada fungsi linguistik yang ditunjukkan oleh penutur (penulis) melalui penggunaan ekspresi linguistik, entitas yang mereka bicarakan/tulis (Ali, 2017). Seperti penyebutan alamat, toko, dan sebagainya dengan dengan menggunakan istilah yang mereka sama-sama tahu.

\section{Pelanggaran Maksim Kualitas}

Penekanan dari maksim ini adalah memberikan kontribusi/informasi sebenar-benarnya dalam sebuah percakapan. Maksim ini memiliki dua sub maksim, yaitu: (a) jangan memberikan informasi yang belum pasti kebenarannya; (b) jangan memberikan informasi yang penutur sendiri tidak punya cukup bukti akan kebenarannya (Senft, 2014). Dari dua submaksim di atas maka didapatkan dua indikator pelanggaran maksim ini, yaitu: (a) Tidak didukung dengan cukup bukti dan (b) Tidak sesuai kenyataan. Penelitian ini menunjukkan bahwa terdapat tiga kecenderungan pelanggaran maksim ini yang memiliki implikatur menerka-nerka, basa-basi, dan berkelit.

Kecenderungan pertama menerka-nerka karena penutur memiliki informasi yang terbatas atas apa yang sedang dibahas. Adalah lazim bagi seorang penutur untuk sengaja bersikap seolah-olah tahu tentang apa yang sedang dibicarakan dengan tujuan agar interaksi tetap berjalan. Sikap seperti ini dalam kajian psikologi termasuk dalam prososial, yaitu bentuk perilaku yang cenderung menguntungkan bagi orang lain. Perilaku yang tercakup di dalamnya adalah memberi rasa aman terhadap orang lain (comforting), saling berbagi, berkerja secara kooperatif, dan menunjukkan sikap empatik terhadap orang lain (Kusmanto, 2011). Bersikap "sok tahu" tidaklah selamanya berkonotasi negatif jika tujuan hal tersebut ingin membuat nyaman mitra tutur dengan menunjukkan antusiasme terhadap topik yang sedang diperbincangkan.

Kecenderungan yang kedua yaitu, basa-basi untuk kesantunan. Bahasa secara garis besar memiliki dua fungsi, yaitu fungsi transaksional dan interaksional. Jika yang pertama merujuk pada Bahasa sebagai alat penyampai informasi, fungsi interaksional merujuk pada fungsi bahasa sebagai sarana menjaga hubungan sosial dalam masyarakat. Salah satu manifestasi dari fungsi interaksional adalah basa-basi (Asmara, 2015). Basa-basi sering digunakan masyarakat Indonesia pada umumnya untuk menunjukkan kesantunan berbahasa mereka.

Kecenderungan yang ke tiga adalah berkelit. Berkelit terkadang membuat penutur berbohong dalam beberapa kondisi. Lazimnya, seorang yang pandai seni retorika akan sangat mudah memainkan kata-kata tanpa berkata bohong dalam sebuah percakapan. Akan tetapi tidak jarang ketika sudah tidak ada ruang untuk berkelit, karena semua bukti penguat jelas, bohong menjadi jalan terakhir yang dilakukan, untuk mempertahankan argumen dan posisinya dalam percakapan tersebut. Berkata bohong masuk dalam kategori memberikan informasi yang tidak sesuai dengan kenyataan yang merupakan indikator dari pelanggaran maksim kualitas. Meskipun terdapat beberapa kasus kebohongan, peneliti tidak berani menyimpulkan bahwa hal tersebut adalah salah satu pola dari komunikasi mahasiswa Sumba. Klaim yang serius dan membutuhkan banyak data pendukung untuk menentukan polanya. 


\section{Pelanggaran Maksim Relevansi}

Maksim Relevansi menitikberatkan pada kontribusi yang relevan sesuai dengan tujuan yang diasumsikan saat ini dari orang-orang yang terlibat dalam percakapan tersebut. Dengan kata lain, kontribusi yang relevan terhadap topik yang sedang dibahas adalah inti dari maksim ini. Maksim ini memiliki satu sub maksim, yaitu be relevant! (Kroeger, 2018), oleh karenanya, indikator pelanggaran yang digunakan adalah keluar topik. Dalam penelitian ini, terdapat kecenderungan pelanggaran maksim ini dengan pola afirmasi. Penutur untuk menunjukkan dukungan dari apa yang disampaikan mitra tutur dengan pernyataan yang tidak relevan dengan topic yang sedang dibahas.

\section{Pelanggaran Maksim Cara}

Maksim yang terakhir dalam prinsip kerjasama adalah maksim cara, yang intinya adalah harus mudah dipahami. Maksim ini memiliki empat submaksim, yaitu: Hindari ketidakjelasan ekspresi, hindari ambiguitas, singkat, teraturlah. Dari empat submaksim ini ditarik empat indikator pelanggaran maksim ini, yaitu: tidak jelas, ambigu, bertele-tele, dan kacau (Kroeger, 2018).

Kecenderungan pelanggaran maksim cara yang ditemukan dalam penelitian ini berpola bertele-tele untuk kesantunan. Hal ini hampir sama dengan yang ditemukan dalam pola pelanggaran maksim kualitas, yaitu basa basi untuk kesantunan. Hal ini sangatlah bergantung pada nilai yang dipegang oleh masing-masing penutur. Terkadang demi kesopanan bertele-tele diperlukan untuk menjaga martabat mitra tutur.

\section{Pembatasan Maksim}

Pembatas maksim adalah kata, frasa, atau ujaran, yang mengekspresikan pikiran penutur dalam membatasi apa yang ingin disampaikan, dengan mempertimbangkan kuantitas, kualitas, relevansi, cara, maupun nilai kesantunan dalam suatu percakapan.

\section{SIMPULAN}

Dari hasil dan pembahasan dari penelitian ini dapat disimpulkan bahwa terdapat beberapa kecenderungan pelanggaran prinsip kerjasama yang dilakukan oleh para mahasiswa multikultural dalam interksi mereka dengan impliktur yang berbeda-beda. Perbedaan implikatur yang muncul disebabkan oleh ikatan primordial kedaerahan masing-masing mahasiswa multikultural. Pelanggaran Maksim Kuantitas memiliki implikatur: penekanan, penyangkalan, dan dalam situasi dimana baik penutur maupun mitra tutur memiliki referensi yang sama dan presupposisi yang tepat pula; Pelanggaran Maksim Kualitas memiliki implikatur sebagai berikut: Menerka-nerka karena tidak yakin atas informasi yang disampaikan, basa-basi untuk kesantunan, menjaga ritme pembicaraan, dan berkelit; Pelanggaran Maksim Relevansi dalam penelitian ini berpola umum: afirmasi terhadap pernyataan atau pendapat mitra tutur; Pelanggaran Maksim Cara memiliki implikatur: menjaga agar percakapan dapat berjalan lebih lama; Pembatasan Maksim Kuantitas memiliki implikatur: memberikan kesan bagi mitra tutur bahwa informasi yang diberikan mungkin tidak cukup lengkap; Pembatasan Maksim Kualitas berpola: penutur tidak bertanggung jawab atas kebenaran ucapannya; Pembatasan Maksim Relevansi berpola: merubah topik pembicaraan tanpa menyinggung mitra tutur; akan tetapi dalam penelitian ini tidak ditemukan Pembatasan Maksim Cara karena terbatasnya data yang diperoleh. 


\section{DAFTAR PUSTAKA}

Achsani, F. (2019). Pematuhan dan Pelanggaran Prinsip Kerja Sama dalam Komunikasi Siswa-Siswi MAN 1 Surakarta Tarling: Journal of Language Education, 2(2), $147-$ 168.

Ali, M. (2017). The Role of the Anaphoric Referential Relations in Facilitating Reading. International Journal of Education and Research, 5(2), 173-180.

Asmara, R. (2015). Basa-basi dalam Percakapan Kolokial Berbahasa Jawa sebagai Penanda Karakter Santun Berbahasa. Transformatika: Jurnal Bahasa, Sastra, dan Pengajarannya, 11(2), 80-95.

Birner, B. J. (2012). Introduction to Pragmatics (Vol. 38). Malden: John Wiley \& Sons.

Grice, H. P. (1991). Studies in the Way of Words. Harvard: Harvard University Press.

Hadiwijaya, M., \& Yahmun, Y. (2017). Kesantunan Berbahasa dalam Iinteraksi Antara Dosen dan Mahasiswa Multikultural DIDAKTIKA: Jurnal Pemikiran Pendidikan, 23(2), 142 154.

Kroeger, P. (2018). Analyzing Meaning: An Introduction to Semantics and Pragmatics. England: Language Science Press.

Kusmanto, A. S. (2011). Empati sebagai Sarana untuk Memperkokoh Sikap Pro-Ssosial Pelajar. Paper presented at the Prosiding Seminar Internasional: Selamatkan Umat dan Bangsa dari Berbagai Krisis, Magelang.

Lestari, I. (2015). Pengaruh Waktu Belajar dan Minat Belajar terhadap Hasil Belajar Matematika. Formatif: Jurnal Ilmiah Pendidikan MIPA, 3(2), 115-125.

Liu, L. (2017). Application of Cooperative Principle and Politeness Principle in Class Question-Answer Process. Theory and Practice in Language Studies, 7(7), 563-569.

Mappau, R. (2017). Konstituen Pengungkap Negasi dalam Bahasa Makassar Dialek Lakiung dan Turatea (Constituent of Negation Expression in Makassarese Language Dialect of Laking and Turatea). SAWERIGADING, 23(1), 127-137.

Parwati, E. (2013). Kohesi Leksikal Repetisi pada Wacana "Wayang Durangpo" dalam Surat Kabar Harian Jawa Pos Edisi Februari-April 2010. Jurnal Artikulasi, 12(2), 807-806.

Rachman, A. K., \& Kinanti, K. P. (2018). Respon Pujian oleh Mahasiswa Multikultural (Studi Kasus dengan Tinjauan Sosiopragmatik). BELAJAR BAHASA, 3(1), 12-22.

Senft, G. (2014). Understanding Pragmatics. New York: Routledge.

Zhou, M. (2009). Cooperative Principle in Oral English Teaching. International Education Studies, 2(3), 42-46. 